Original Research

\title{
Metal-Humus Acid Nanoparticles - Synthesis, Characterization and Molecular Modeling
}

\author{
Kinga I. Hęclik ${ }^{1}$, Karol Hęclik ${ }^{2 *}$, Iwona Zarzyka ${ }^{3}$ \\ ${ }^{1}$ Faculty of Biology and Biotechnology, University of Rzeszow, Poland \\ ${ }^{2}$ Department of Biotechnology and Bioinformatics, Faculty of Chemistry, Rzeszow University of Technology, \\ Rzeszów, Poland \\ ${ }^{3}$ Department of Organic Chemistry, Faculty of Chemistry, Rzeszow University of Technology, \\ Rzeszów, Poland
}

Received: 26 May 2020

Accepted: 15 October 2020

\begin{abstract}
It was found, the following ions of heavy metal: $\mathrm{Ru}, \mathrm{Rh}, \mathrm{Pd}, \mathrm{Ag}, \mathrm{Os}, \mathrm{Ir}, \mathrm{Pt}$ or $\mathrm{Au}$ are aggregated in humic acids. This gave an idea to create a tool that would detoxify soil (contaminated by heavy metals) by phytoremediation using the peat in suitable reaction composition. In the work nanoparticles with the use of humic/fulvic acid and silver, zirconium and copper have been produced and they have been analyzed by Nanoparticle Tracking Analysis, Dynamic Light Scattering, Scanning Electron Microscopy and Transmission Electron Microscopy methods. Moreover, molecular modeling of fulvic acid and humic acid have been performed with the use of DFT methods. The fulvic acid molecule forms only salt with the tested metal ions. The structure of humic acid molecule allows the coordination of the metal ion by means of three single bonds. It results in formation of the specific conformation of molecule with "the window" which diameter is about $7.3 \AA$ and depends on the size of tested metal ion. This molecule conformation is responsible for the metal ion catching. The modeling of humus acids allowed to determine the most stable conformation, the places of potential attachment, and help in visualization the model of the obtained nanoparticle.
\end{abstract}

Keywords: nanoparticles, humic acid, fulvic acid, molecular modeling, peat

\section{Introduction}

In the scientific literature, there is a clear lack of information about deciphering of possible mechanisms of creating metal nanoparticles. The methods described so far are primarily based on the enzymatic reduction (dehydrogenase) relied on the nicotinamidoadenine-

*e-mail:kheclik@prz.edu.pl dinucleotide (NADH) oxidation [1]. In simultaneous oxidation-reducing reactions, the proper environment was created because of need for reducing metal cations, most often to the form of non-reactive metallic nanoparticles. Similar applications were also shown by reducing sugars [2] or flawonoids [3-6], as examples of chemical compounds of natural origin. The idea of formation nanoparticles was based on the use of an environment that had properties of reducing metal cations to inert particles having most often nanometric dimensions. With the increase in public awareness 
of the degradations the natural environment caused by human activity, as well as the development and improvement of living standards, the researchers paid their attention to the using renewable resources in the production of medicaments, plastics or even nanoparticles.

The idea of humus acids, as elements catching and deactivating metal ions, was taken from nature, which in spite of appearances often better than human manages with various threats and finds ways to neutralize them. In the area of Amur River on the coastal peat bogs, humus acids with aggregated ions of such metal like: $\mathrm{Ru}, \mathrm{Rh}, \mathrm{Pd}, \mathrm{Ag}, \mathrm{Os}, \mathrm{Ir}, \mathrm{Pt}$ or $\mathrm{Au}$ were found [7-9]. It gave some kind of hope for creating a tool that would detoxify soil contaminated with heavy metals by phytoremediation using peat with right composition and value of $\mathrm{pH}$.

The presence of organic matter in the form of composts or sewage sludge in soils may lead to an uncontrolled increase in the solubility of heavy metals as a result of the formation complexes with low-molecular organic substances $[10,11]$ or as a result of a change in $\mathrm{pH}$. Plant residues may be also an additional source of organic matter in remediated contaminated soils. The phytostabilization of heavy metal contaminated areas with the use of grasses and other herbaceous plants or trees leads to the formation of litter on the surface of forested soils, followed by their decomposition and release of low-molecular organic acids. It may cause complexation or chelation of heavy metals and their leaching deep into the soil $[12,13]$.

In order to immobilize heavy metals in soils, liming ( $\mathrm{pH}$ modification) and increasing the sorption capacity of soils by the application of organic matter,i.e. synthetic sorbents or materials rich in clay fractions [14]. However, it can be done with the use of natural substance like peat.

Engebretson and von Wandruszka [15] postulated that humic acids (found in peats) can be considered as flexible linear polymers in concentrations lower than $3.5 \mathrm{~g} / \mathrm{dm}^{3}$ with ionic strength less than $0.05 \mathrm{~mol} / \mathrm{dm}^{3}$. They claimed high possibility that humic acids will aggregate by introducing, e.g. ions of metals, into peat soils due to interaction between molecules of humic acids as well intramolecular in single molecule of humic acid. They also proposed the formation of domains similar to micelles by the humic acid molecules.

For this purpose many scientists in the world were carried out a number of laboratory experiments with the use of the microbes, yeast or plant extracts [7] resulting in metal nanoparticles, their oxides and coreshell composites [16]. An attempt of determining the nanoparticle formation mechanism in such experiments became the most important problem.

Most likely, an indication which compounds really allow to form nanoparticles can be facilitated by the use of quantum-mechanical calculations [17]. In this way, the structures of selected organic compounds (flavonoids, terpenoids, ketones, aldehydes, etc.) and inorganic compounds (metal salts and oxides) can be optimized (with the use of appropriate applications) to the energetically beneficial form, which could be the precursor of the reaction. Determining the spatial arrangement of the side chains as well as analyzing the distribution of electron density within the molecule, can help indicate the places of potential interaction the metal cations to the analyzed compound. In addition, the possibility of optimizing the nanoparticle hypothetical structure may allow to determine whether such a form of the particle is stable and thus whether it can form.

In the work, the nanoparticles of humus acids with silver, zirconium and copper ions were prepared and they were characterized by the following methods: nanoparticle tracking analysis (NTA) [18], dynamic light scattering (DLS) [19], scanning electron microscopy (SEM) [19-21] and transmission electron microscopy (TEM) [20, 21]. The molecular modeling of humus acids was also performed. The experimental and calculation results were in accordance.

Moreover, this paper was mainly an attempt to face the purpose fullness and possibilities of using molecular modeling in relation to the results of laboratory experiments in the context of compounds with an extensive spatial structure which are humic acids.

\section{Material and Methods}

\section{Materials}

Commercially available peat mixtures were used as the basic raw material with $\mathrm{pH}=3.5-8.0$ (producer: Agaris Poland Sp. z o.o.; HOLLAS and STERLUX) to the synthesis of metal nanoparticles. Their salts, which have good solubility in an aqueous environment $\left(\mathrm{CuSO}_{4}, \mathrm{AgNO}_{3}, \mathrm{Zr}\left(\mathrm{NO}_{3}\right)_{2}\right.$ - producer Sigma-Aldrich Corp., St. Louis, MO, US) were source of metal ions. Peat mixtures were the base material for the production of aqueous extracts. The percentage content of humic acids to fulvic acids in individual samples determined using fractional composition analysis of mineral soil humus by the Tiurin method [22] equaled 2:1, respectively.

\section{Nanoparticle Preparation}

Nanoparticles were synthesized by three methods (M1, M2, M3) using two types of peat HOLLAS (HL) and STERLUX (ST) in samples with increasing peat content $(0.01 \mathrm{~g} ; 0.1 \mathrm{~g} ; 1.0 \mathrm{~g} ; 10.0 \mathrm{~g} ; 25.0 \mathrm{~g} ; 50.0 \mathrm{~g}$; $100.0 \mathrm{~g} ; 150 \mathrm{~g})$.

The M1 method consisted in preparation of the peat extracts by shaking peat with distilled water. Undissolved organic residue (e.g. parts of stalk, root or bark) were drained and subsequent salts $\left(\mathrm{CuSO}_{4} \cdot 5 \mathrm{H}_{2} \mathrm{O}\right.$, $\left.\mathrm{AgNO}_{3}, \mathrm{Zr}\left(\mathrm{NO}_{3}\right)_{2}\right)$ were weighted into the liquid. Nanoparticles in the form of ginger/foxy sediment (nano- $\mathrm{Cu}$ ), black thin film on the walls of the vessel 
(nano-Ag) and orange/cream fluffy sediment (nano$\mathrm{Zr}$ ) were obtained in 10 minutes after mixing the salt with the filtrate. This method was created to accurately reproduce the conditions in the peat bog.

The M2 method differed from the M1 method in one point. After shaking the peat with water, the content of the flask was heated to boiling. The remaining steps were carried out identically as in M1. As a result of the reaction, metal nanoparticles were obtained in the form of: red sediment (nano- $\mathrm{Cu}$ ), black sediment with metallic gloss (nano-Ag) and brown-white fluffy sediment (nano-Zr). This method was an attempt of confirmation or deny the hypothesis of spontaneous formation of nanoparticles in a peat bog during intense sunlight (e.g. during a very hot summer).

The M3 method differed from the previous ones in the final stage of preparation the peat extract. After shaking and filtration, the extract was concentrated to a sample volume of $50 \mathrm{ml}$. The application of this type of method was to present a method of creating nanoparticles during drought. In this way, the obtained nanoparticles were: dark brown coating on the vessel wall (nano- $\mathrm{Cu}$ ), black matt sediment at the bottom of the vessel (nano-Ag) and dirty beige sediment at the bottom of the vessel (nano-Zr).

\section{Nanoparticle Tracking Analysis (NTA)}

The size of the analyzed samples was determined using the nanoparticle tracking analysis (NTA). It is a direct method of a quick visualization and analysis of nanoparticles during the measurement of samples in a liquid state.

Prior to the determination of the size distribution of the synthesized nanoparticles, each sample was diluted to the concentration of nanoparticles equals $0.01 \mu \mathrm{L}$ per one $\mu \mathrm{L} \mathrm{H}_{2} \mathrm{O}$ in the stock solution. Next, in order to break up agglomerates of nanoparticles, all samples were sonicated, in the ice bath for $10 \mathrm{~min}$, providing energy of approx. 4000 J. The prepared suspension (ca. $500 \mu \mathrm{L}$ ) was transferred to a glass plate which was put in a microscope. After illuminating the sample with a laser beam, a sharp image of nanoparticles was obtained. The specialized software automatically analyzed the Brownian motions of each nanoparticles and calculated their hydrodynamic diameter. Each measurement lasted 90 s. Short video was recorded during the measurement as well as size of each nanoparticles and average size of population were determined.

\section{Dynamic Light Scattering (DLS)}

The zeta potential of the synthesized metal nanoparticles was measured at temperature of $25^{\circ} \mathrm{C}$ using a Malvern Zetasizer Nano ZS particle size apparatus with dynamic light scattering (DLS). The analyzed samples were diluted 1:10 with distilled water. Measurement of each samples was made three times.

\section{Transmission Electron Microscopy (TEM)}

Morphology of the obtained metal nanoparticles was analyzed using a transmission electron microscope Philips CM-20 SuperTwin (accelerating voltage: $200 \mathrm{kV}$, point to point resolution: $0.24 \mathrm{~nm}$ ). The agglomerated nanoparticle samples grated in an agate mortar were transferred from a mixture of 2-propanol to thin-film carbon meshes. Afterward samples were placed in a vacuum chamber of a microscope and analyzed using a Gatan TV622 camera.

\section{Scanning Electron Microscopy (SEM)}

The analysis of the synthesized metal nanoparticles was performed using a Philips 515 scanning electron microscope (accelerating voltage: up to $30 \mathrm{kV}$, resolution: $5 \mathrm{~nm}$ ) with EDS (EDAX Genesis) spectrometer. Grated in an agate mortar, the samples were applied to a tape placed on a microscope table. The surface of the samples was sprayed with a thin layer of carbon to avoid charging from an electron beam. The prepared samples were placed in a vacuum chamber to carry out the experiment.

\section{Quantum-Mechanical Calculation}

The necessary quantum-mechanical calculations were made using the Density Functional Theory (DFT), which was implemented in Gaussian application [23]. This application was available for authors in Interdisciplinary Centre for Mathematical and Computational Modelling in Warsaw under the grant No. G49-12. The main goal of structure optimization using DFT methods is to find the lowest value of the total energy of compounds.

From the proven and widely used in organic chemistry functionals, the B3LYP (Becke 3-term correlation functional; Lee, Yang, and Parr exchange functional) was chosen. Due to the copper, silver and zirconium ions present in the studied compounds, a 3-21 basis-set was used.

The GaussView software were used to perform the visualizations of structure.

\section{Results and Discussion}

\section{Results}

Green synthesis methods are simple, easy and pleasant, that's why a lot of scientists use the usual reduction reactions initiated with the use of natural chemical compounds [24-29].

It is known that peat is a mixture of humic acids and fulvic acids. Their structures were presented in Fig. 1. The share of humic acids is twice higher than fulvic acids in the used peat $[30,31]$. The size of the obtained particles peat with silver, zirconium and cooper was 


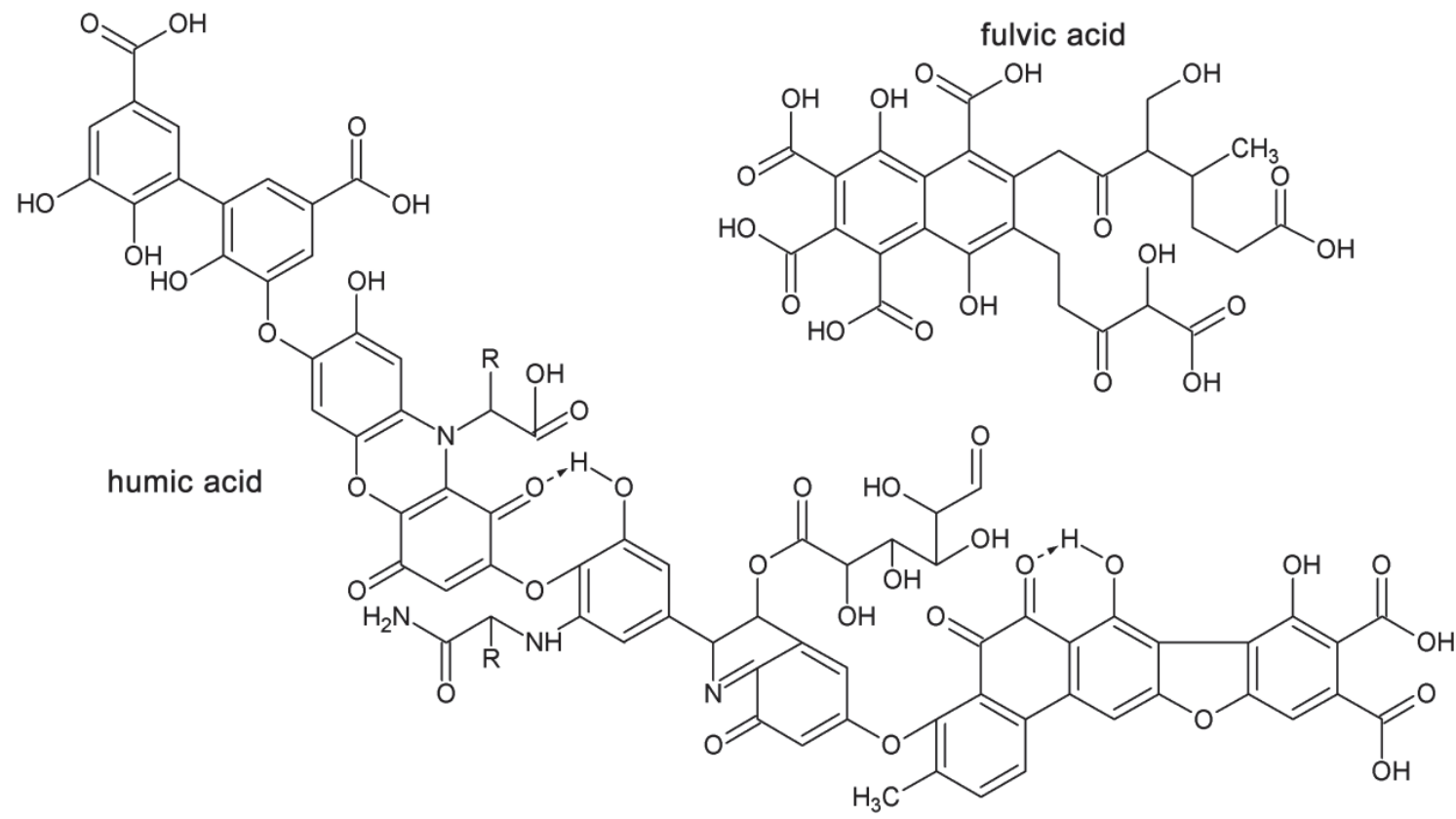

Fig. 1. Structure of humic acid and fulvic acid; $\mathrm{R}$ can be $\mathrm{H}-$ or $\mathrm{CH}_{3}-$ or $\mathrm{CH}_{3}-\mathrm{CH}_{2}-$ -

measured by NTA. As shown in a Fig. 2, the size of the resulting nanoparticles depends on the amount of humic acids used in the synthesis. They were synthesized in a series of samples with increasing amount of humic acids. The obtained silver particles have the smallest size, usually smaller than $50 \mathrm{~nm}$. Copper and zirconium particles were similar size and bigger than silver ones. Their particle size was not higher than $200 \mathrm{~nm}$.

Such big size of the resulting particles was caused by aggregation and sedimentation of them. Both, sonication and attempts at mechanical separation of the aggregates were unsuccessful. It was possible to distinguish a single particle but there impossible to separate the agglomerates into single nanoparticles in order to accurately measure.

The plots shown in the Fig. 2 are based on a data shown in the Table 1 where mean is mean average from three measures, $S D$ means standard deviation and the $p$ is $p$-value. Bolded values are statistically significant.

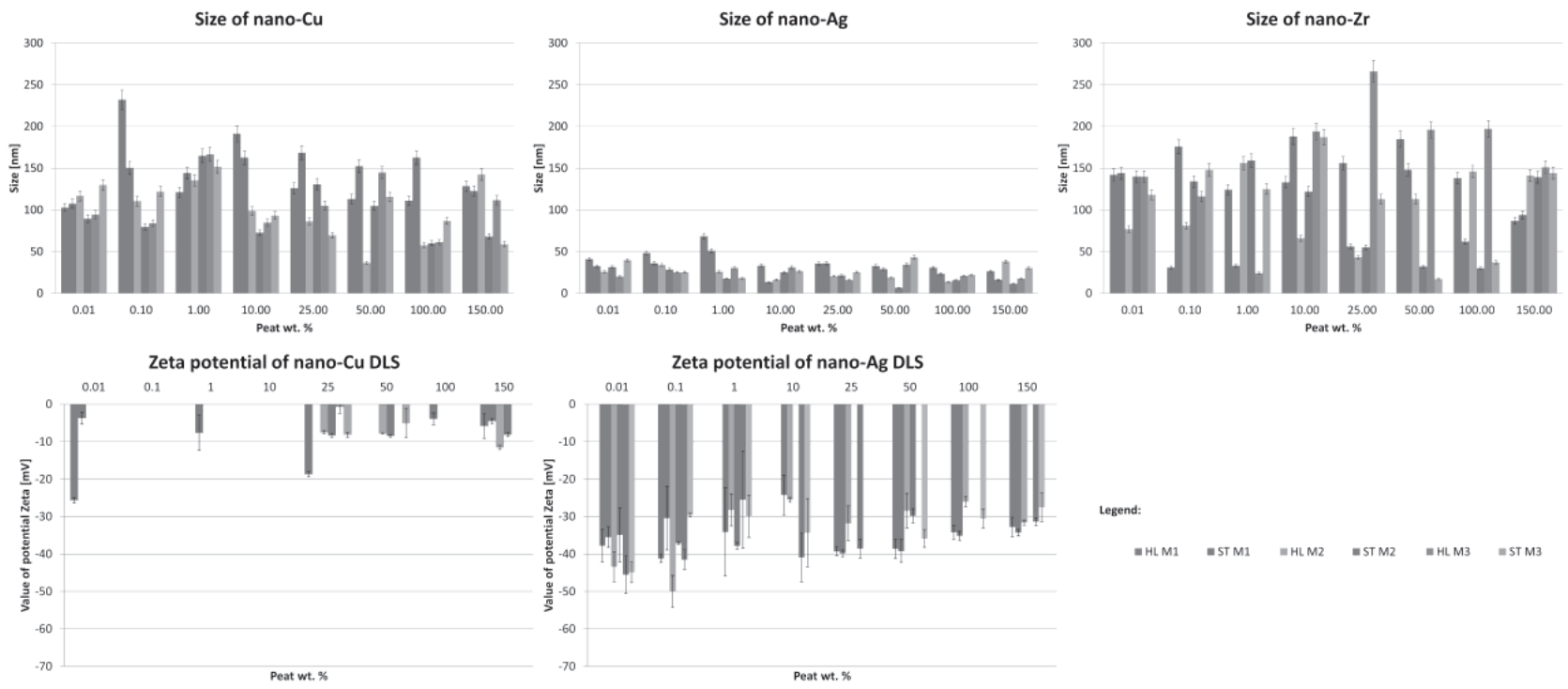

Fig. 2. Size distribution and zeta potential of nanoparticles of humic acid with coordinated cooper, silver and zirconium (nano-Cu, nanoAg, nano-Zr). M1, M2, M3 means the method of nanoparticles preparation described in Experimental Part. HL and ST means the type of peat described in Materials part. 
Table 1. Size distribution of nanoparticles $\mathrm{Cu}, \mathrm{Ag}$ and $\mathrm{Zr}$ (nano-Cu, nano-Ag, nano-Zr). M1, M2, M3 means the method of nanoparticles preparation described in Part Materials and methods. HL and ST means the type of peat described in Part Materials and Methods.

\begin{tabular}{|c|c|c|c|c|c|c|c|c|c|c|}
\hline \multirow{2}{*}{ Nano-particle } & \multirow{2}{*}{$\begin{array}{c}\text { Method \& Type } \\
\text { of peat }\end{array}$} & \multirow{2}{*}{$\begin{array}{l}\text { Statistical } \\
\text { parameter }\end{array}$} & \multicolumn{8}{|c|}{ No. of sample } \\
\hline & & & 1 & 2 & 3 & 4 & 5 & 6 & 7 & 8 \\
\hline \multirow{18}{*}{ Nano-Cu } & \multirow{3}{*}{ M1 HL } & Mean [nm] & 102.7 & 232.0 & 121.3 & 191.3 & 126.0 & 113.0 & 111.0 & 128.3 \\
\hline & & $\mathrm{SD}[\mathrm{nm}]$ & 5.13 & 11.60 & 6.07 & 9.57 & 6.30 & 5.65 & 5.55 & 6.42 \\
\hline & & $\mathrm{p}$ & 1.000 & 0.811 & 1.000 & 0.997 & 1.000 & 1.000 & 1.000 & 1.000 \\
\hline & \multirow{3}{*}{ M1 ST } & Mean [nm] & 107.3 & 150.3 & 144.3 & 162.7 & 168.3 & 152.3 & 162.7 & 122.7 \\
\hline & & $\mathrm{SD}[\mathrm{nm}]$ & 5.37 & 7.52 & 7.22 & 8.13 & 8.42 & 7.62 & 8.13 & 6.13 \\
\hline & & $\mathrm{p}$ & 0.999 & 0.869 & 0.924 & 0.701 & 0.609 & 0.846 & 0.701 & 0.997 \\
\hline & \multirow{3}{*}{ M2 HL } & Mean $[\mathrm{nm}]$ & 116.7 & 110.3 & 135.3 & 98.7 & 86.0 & 36.3 & 57.7 & 142.3 \\
\hline & & $\mathrm{SD}[\mathrm{nm}]$ & 5.83 & 5.52 & 6.77 & 4.93 & 4.30 & 1.82 & 2.88 & 7.12 \\
\hline & & $\mathrm{p}$ & 0.860 & 0.797 & 0.970 & 0.655 & 0.488 & 0.074 & 0.188 & 0.987 \\
\hline & \multirow{3}{*}{ M2 ST } & Mean $[\mathrm{nm}]$ & 89.3 & 79.7 & 164.7 & 72.7 & 130.7 & 104.7 & 60.0 & 68.0 \\
\hline & & $\mathrm{SD}[\mathrm{nm}]$ & 4.47 & 3.98 & 8.23 & 3.63 & 6.53 & 5.23 & 3.00 & 3.40 \\
\hline & & $\mathrm{p}$ & 0.998 & 0.989 & 1.000 & 0.969 & 1.000 & 0.999 & 0.879 & 0.945 \\
\hline & \multirow{3}{*}{ M3 HL } & Mean [nm] & 94.3 & 84.0 & 166.7 & 84.7 & 105.0 & 144.7 & 61.3 & 111.7 \\
\hline & & $\mathrm{SD}[\mathrm{nm}]$ & 4.72 & 4.20 & 8.33 & 4.23 & 5.25 & 7.23 & 3.07 & 5.58 \\
\hline & & $\mathrm{p}$ & 0.599 & 0.462 & 0.999 & 0.470 & 0.735 & 0.990 & 0.218 & 0.811 \\
\hline & \multirow{3}{*}{ M3 ST } & Mean [nm] & 129.7 & 122.0 & 151.7 & 93.3 & 69.7 & 115.7 & 87.0 & 59.0 \\
\hline & & $\mathrm{SD}[\mathrm{nm}]$ & 6.48 & 6.10 & 7.58 & 4.67 & 3.48 & 5.78 & 4.35 & 2.95 \\
\hline & & $\mathrm{p}$ & 0.999 & 0.999 & 1.000 & 0.978 & 0.777 & 0.999 & 0.951 & 0.609 \\
\hline \multirow{18}{*}{ Nano-Ag } & \multirow{3}{*}{ M1 HL } & Mean [nm] & 41.0 & 48.3 & 68.3 & 33.0 & 35.7 & 32.7 & 30.7 & 26.3 \\
\hline & & $\mathrm{SD}[\mathrm{nm}]$ & 2.05 & 2.42 & 3.42 & 1.65 & 1.78 & 1.63 & 1.53 & 1.32 \\
\hline & & $\mathrm{p}$ & 0.976 & 0.773 & 0.051 & 0.999 & 0.999 & 0.999 & 0.999 & 1.000 \\
\hline & \multirow{3}{*}{ M1 ST } & Mean $[\mathrm{nm}]$ & 32.3 & 36.0 & 51.0 & 13.3 & 36.0 & 29.0 & 23.3 & 16.3 \\
\hline & & $\mathrm{SD}[\mathrm{nm}]$ & 1.62 & 1.80 & 2.55 & 0.67 & 1.80 & 1.45 & 1.17 & 0.82 \\
\hline & & $\mathrm{p}$ & 0.999 & 1.000 & 1.000 & 0.343 & 1.000 & 0.999 & 0.936 & 0.541 \\
\hline & \multirow{3}{*}{ M2 HL } & Mean $[\mathrm{nm}]$ & 25.7 & 34.0 & 25.7 & 16.3 & 20.3 & 18.7 & 13.7 & 38.0 \\
\hline & & $\mathrm{SD}[\mathrm{nm}]$ & 1.28 & 1.70 & 1.28 & 0.82 & 1.02 & 0.93 & 0.68 & 1.90 \\
\hline & & $\mathrm{p}$ & 0.221 & 0.606 & 0.221 & 0.042 & 0.090 & 0.066 & 0.024 & 0.963 \\
\hline & \multirow{3}{*}{ M2 ST } & Mean $[\mathrm{nm}]$ & 31.3 & 28.3 & 17.3 & 25.0 & 21.3 & 6.7 & 15.7 & 11.3 \\
\hline & & $\mathrm{SD}[\mathrm{nm}]$ & 1.57 & 1.42 & 0.87 & 1.25 & 1.07 & 0.33 & 0.78 & 0.57 \\
\hline & & $\mathrm{p}$ & 0.936 & 0.807 & 0.155 & 0.588 & 0.343 & 0.009 & 0.106 & 0.035 \\
\hline & \multirow{3}{*}{ M3 HL } & Mean [nm] & 20.0 & 25.0 & 30.3 & 31.0 & 16.0 & 34.3 & 21.0 & 17.3 \\
\hline & & $\mathrm{SD}[\mathrm{nm}]$ & 1.00 & 1.25 & 1.52 & 1.55 & 0.80 & 1.72 & 1.05 & 0.87 \\
\hline & & $\mathrm{p}$ & 0.085 & 0.200 & 0.416 & 0.449 & 0.040 & 0.624 & 0.102 & 0.051 \\
\hline & \multirow{3}{*}{ M3 ST } & Mean [nm] & 39.7 & 25.3 & 18.3 & 26.3 & 25.3 & 43.0 & 21.7 & 30.3 \\
\hline & & $\mathrm{SD}[\mathrm{nm}]$ & 1.98 & 1.27 & 0.92 & 1.32 & 1.27 & 2.15 & 1.08 & 1.52 \\
\hline & & $\mathrm{p}$ & 0.999 & 0.612 & 0.193 & 0.681 & 0.612 & 1.000 & 0.363 & 0.902 \\
\hline
\end{tabular}


Table 1. Continued.

\begin{tabular}{|c|c|c|c|c|c|c|c|c|c|c|}
\hline \multirow{18}{*}{ Nano-Zr } & \multirow{3}{*}{ M1 HL } & Mean $[\mathrm{nm}]$ & 142.0 & 31.0 & 124.0 & 133.0 & 156.3 & 185.0 & 138.0 & 87.0 \\
\hline & & $\mathrm{SD}[\mathrm{nm}]$ & 7.10 & 1.55 & 6.20 & 6.65 & 7.80 & 9.25 & 6.90 & 4.35 \\
\hline & & $\mathrm{p}$ & 0.612 & 0.729 & 0.009 & 1.000 & 0.363 & 0.825 & 0.988 & 0.999 \\
\hline & \multirow{3}{*}{ M1 ST } & Mean $[\mathrm{nm}]$ & 144.0 & 176.0 & 33.0 & 188.0 & 56.0 & 148.0 & 62.0 & 94.0 \\
\hline & & $\mathrm{SD}[\mathrm{nm}]$ & 7.20 & 8.80 & 1.65 & 9.40 & 2.80 & 7.40 & 3.10 & 4.70 \\
\hline & & $\mathrm{p}$ & 0.071 & 0.083 & 1.000 & 0.030 & 0.999 & 0.095 & 0.999 & 0.986 \\
\hline & \multirow{3}{*}{ M2 HL } & Mean [nm] & 77.0 & 81.0 & 156.0 & 66.0 & 43.0 & 113.0 & 146.0 & 141.0 \\
\hline & & $\mathrm{SD}[\mathrm{nm}]$ & 3.85 & 4.05 & 7.80 & 3.30 & 2.15 & 5.65 & 7.30 & 7.05 \\
\hline & & $\mathrm{p}$ & 0.862 & 0.867 & 0.995 & 0.925 & 0.785 & 0.995 & 0.971 & 0.999 \\
\hline & \multirow{3}{*}{ M2 ST } & Mean $[\mathrm{nm}]$ & 140.0 & 134.0 & 159.0 & 122.0 & 55.0 & 32.0 & 30.0 & 139.0 \\
\hline & & $\mathrm{SD}[\mathrm{nm}]$ & 7.00 & 6.70 & 7.95 & 6.10 & 2.75 & 1.60 & 1.50 & 6.95 \\
\hline & & $\mathrm{p}$ & 1.000 & 0.999 & 1.000 & 0.999 & 0.241 & 0.097 & 0.120 & 0.999 \\
\hline & \multirow{3}{*}{ M3 HL } & Mean $[\mathrm{nm}]$ & 140.0 & 116.0 & 24.0 & 194.0 & 226.0 & 196.0 & 197.0 & 151.0 \\
\hline & & $\mathrm{SD}[\mathrm{nm}]$ & 7.00 & 5.80 & 1.20 & 9.70 & 13.30 & 9.80 & 9.85 & 7.55 \\
\hline & & $\mathrm{p}$ & 1.000 & 1.000 & 1.000 & 0.823 & 0.999 & 0.999 & 0.998 & 1.000 \\
\hline & \multirow{3}{*}{ M3 ST } & Mean $[\mathrm{nm}]$ & 118.0 & 148.0 & 125.0 & 187.0 & 113.0 & 17.0 & 37.0 & 144.0 \\
\hline & & $\mathrm{SD}[\mathrm{nm}]$ & 5.90 & 7.40 & 6.25 & 9.35 & 5.65 & 0.85 & 1.85 & 7.20 \\
\hline & & $\mathrm{p}$ & 0.999 & 1.000 & 0.997 & 1.000 & 0.999 & 0.030 & 0.126 & 0.990 \\
\hline
\end{tabular}

The nanoparticles of humic acid with silver were the smallest and their zeta potential was smaller than $-30 \mathrm{mV}$. On the other hand, nanoparticles with zirconium and copper were 4-5 times bigger and had zeta potential in the range $-24 \div 0 \mathrm{mV}$. The example plot of zeta potential for silver and copper nanoparticles was shown in Fig. 2.

The plots shown in Fig. 2 are based on a data shown in the Table 2, where mean is mean average from three measures, $S D$ means standard deviation and the $p$ is $\mathrm{p}$-value. Bolded values are statistically significant.

SEM analysis confirmed the NTA results and it was illustrated in Fig. 3. The SEM-EDX analysis of the obtained particles samples confirmed the share of silver, zirconium and copper in their structure. The calculated share of silver, zirconium and copper was $9.68 ; 8.28$ and $5.92 \%$ by mass whereas the measured ones $9.69 ; 11.92$ and 6.22 , respectively. Calculations were made knowing that the share of fulvic acid in peat is 2 times higher than that of humic acid. In order to estimate the size of the resulted nanoparticles, TEM analysis was performed and the nanoparticles diameter is about $5 \mathrm{~nm}$.

The conducted molecular modeling of fulvic acid and humic acid resulted in the existence of only one metal-acid bond in a fulvic acid salt. In contrast, the humic acid molecule coordinates the metal ion with three single bonds. The calculated molecule structure was shown in Fig. 4 (left). The humic acid conformation is agreed with the specific spatial structure of the humic acid molecule proposed by Wandruszka's and visible in Fig. 4 (right) [32].

The considered fold creates a space (indicates by "\#” in Fig. 5) that can trap a metal ion. One can also see that the second place of potential attachment of a metal ion (marked with "*" in Fig. 5). However, the probability of an attachment is much smaller. The oxygen atoms in this fragment come from hydroxyl groups, while in the case of the fragment marked with the symbol "\#”, oxygen atoms come from carbonyl groups and third place of coordination derives from nitrogen atom.

Moreover, the folding of humic acid molecule resulted in formation of a "window" with diameter about $7.3 \AA$ is clearly seen in Fig. 6 .

Our calculations made it possible to compare the length of bonds formed in nanoparticles with the existing literature data (Table 3).

Sample data for nanoparticles composed of one humic acid structure and one metal ion in position ,\#” were presented in Table 5 and Table 6 . In addition, the values of the bond length between the metal ion and the oxygen and nitrogen atoms, in relation to the values derived from molecular modeling and the values from Table 3 were compared in Table 6.

Sample data for nanoparticles composed of one humic acid structure and one metal ion in position ,\#” were presented in Table 5 and Table 6 . In addition, the values of the bond length between the metal ion and the oxygen and nitrogen atoms, in relation to the values 
Table 2. Zeta potential of nanoparticles $\mathrm{Cu}$ and $\mathrm{Ag}$ (nano- $\mathrm{Cu}$, nano- $\mathrm{Ag}$ ). M1, M2, M3 means the method of nanoparticles preparation described in Part Materials and methods. HL and ST means the type of peat described in Part Materials and Methods.

\begin{tabular}{|c|c|c|c|c|c|c|c|c|c|c|}
\hline \multirow{2}{*}{ Nano-particle } & \multirow{2}{*}{$\begin{array}{c}\text { Method \& Type } \\
\text { of peat }\end{array}$} & \multirow{2}{*}{$\begin{array}{l}\text { Statistical } \\
\text { parameter }\end{array}$} & \multicolumn{8}{|c|}{ No. of sample } \\
\hline & & & 1 & 2 & 3 & 4 & 5 & 6 & 7 & 8 \\
\hline \multirow{18}{*}{ Nano-Cu } & \multirow{3}{*}{ M1 HL } & Mean $[\mathrm{mV}]$ & -25.7 & $\mathrm{n} / \mathrm{a}$ & $\mathrm{n} / \mathrm{a}$ & $\mathrm{n} / \mathrm{a}$ & -18.7 & $\mathrm{n} / \mathrm{a}$ & $\mathrm{n} / \mathrm{a}$ & -5.8 \\
\hline & & $\mathrm{SD}[\mathrm{mV}]$ & 0.74 & $\mathrm{n} / \mathrm{a}$ & $\mathrm{n} / \mathrm{a}$ & $\mathrm{n} / \mathrm{a}$ & 0.70 & $\mathrm{n} / \mathrm{a}$ & $\mathrm{n} / \mathrm{a}$ & 3.26 \\
\hline & & $\mathrm{p}$ & 0.001 & $\mathrm{n} / \mathrm{a}$ & $\mathrm{n} / \mathrm{a}$ & $\mathrm{n} / \mathrm{a}$ & 0.001 & $\mathrm{n} / \mathrm{a}$ & $\mathrm{n} / \mathrm{a}$ & 0.999 \\
\hline & \multirow{3}{*}{ M1 ST } & Mean $[\mathrm{mV}]$ & -3.7 & $\mathrm{n} / \mathrm{a}$ & -7.6 & $\mathrm{n} / \mathrm{a}$ & $\mathrm{n} / \mathrm{a}$ & $\mathrm{n} / \mathrm{a}$ & -3.9 & -4.5 \\
\hline & & $\mathrm{SD}[\mathrm{mV}]$ & 1.64 & $\mathrm{n} / \mathrm{a}$ & 4.68 & $\mathrm{n} / \mathrm{a}$ & $\mathrm{n} / \mathrm{a}$ & $\mathrm{n} / \mathrm{a}$ & 1.6 & 0.63 \\
\hline & & $\mathrm{p}$ & 0.637 & $\mathrm{n} / \mathrm{a}$ & 0.001 & $\mathrm{n} / \mathrm{a}$ & $\mathrm{n} / \mathrm{a}$ & $\mathrm{n} / \mathrm{a}$ & 0.475 & 0.200 \\
\hline & \multirow{3}{*}{ M2 HL } & Mean $[\mathrm{mV}]$ & $\mathrm{n} / \mathrm{a}$ & $\mathrm{n} / \mathrm{a}$ & $\mathrm{n} / \mathrm{a}$ & $\mathrm{n} / \mathrm{a}$ & -7.5 & -7.8 & $\mathrm{n} / \mathrm{a}$ & -11.5 \\
\hline & & $\mathrm{SD}[\mathrm{mV}]$ & $\mathrm{n} / \mathrm{a}$ & $\mathrm{n} / \mathrm{a}$ & $\mathrm{n} / \mathrm{a}$ & $\mathrm{n} / \mathrm{a}$ & 0.45 & 0.13 & $\mathrm{n} / \mathrm{a}$ & 0.5 \\
\hline & & $\mathrm{p}$ & $\mathrm{n} / \mathrm{a}$ & $\mathrm{n} / \mathrm{a}$ & $\mathrm{n} / \mathrm{a}$ & $\mathrm{n} / \mathrm{a}$ & 0.018 & 0.006 & $\mathrm{n} / \mathrm{a}$ & 0.001 \\
\hline & \multirow{3}{*}{ M2 ST } & Mean $[\mathrm{mV}]$ & $\mathrm{n} / \mathrm{a}$ & $\mathrm{n} / \mathrm{a}$ & $\mathrm{n} / \mathrm{a}$ & $\mathrm{n} / \mathrm{a}$ & -8.3 & -8.5 & $\mathrm{n} / \mathrm{a}$ & -8.1 \\
\hline & & $\mathrm{SD}[\mathrm{mV}]$ & $\mathrm{n} / \mathrm{a}$ & $\mathrm{n} / \mathrm{a}$ & $\mathrm{n} / \mathrm{a}$ & $\mathrm{n} / \mathrm{a}$ & 0.53 & 0.32 & $\mathrm{n} / \mathrm{a}$ & 0.51 \\
\hline & & $\mathrm{p}$ & $\mathrm{n} / \mathrm{a}$ & $\mathrm{n} / \mathrm{a}$ & $\mathrm{n} / \mathrm{a}$ & $\mathrm{n} / \mathrm{a}$ & 1.000 & 1.000 & $\mathrm{n} / \mathrm{a}$ & 1.000 \\
\hline & \multirow{3}{*}{ M3 HL } & Mean $[\mathrm{mV}]$ & $\mathrm{n} / \mathrm{a}$ & $\mathrm{n} / \mathrm{a}$ & $\mathrm{n} / \mathrm{a}$ & $\mathrm{n} / \mathrm{a}$ & -7.2 & $\mathrm{n} / \mathrm{a}$ & $\mathrm{n} / \mathrm{a}$ & $\mathrm{n} / \mathrm{a}$ \\
\hline & & $\mathrm{SD}[\mathrm{mV}]$ & $\mathrm{n} / \mathrm{a}$ & $\mathrm{n} / \mathrm{a}$ & $\mathrm{n} / \mathrm{a}$ & $\mathrm{n} / \mathrm{a}$ & 1.72 & $\mathrm{n} / \mathrm{a}$ & $\mathrm{n} / \mathrm{a}$ & $\mathrm{n} / \mathrm{a}$ \\
\hline & & $\mathrm{p}$ & $\mathrm{n} / \mathrm{a}$ & $\mathrm{n} / \mathrm{a}$ & $\mathrm{n} / \mathrm{a}$ & $\mathrm{n} / \mathrm{a}$ & 0.036 & $\mathrm{n} / \mathrm{a}$ & $\mathrm{n} / \mathrm{a}$ & $\mathrm{n} / \mathrm{a}$ \\
\hline & \multirow{3}{*}{ M3 ST } & Mean $[\mathrm{mV}]$ & $\mathrm{n} / \mathrm{a}$ & $\mathrm{n} / \mathrm{a}$ & $\mathrm{n} / \mathrm{a}$ & $\mathrm{n} / \mathrm{a}$ & -8.2 & -5.1 & $\mathrm{n} / \mathrm{a}$ & $\mathrm{n} / \mathrm{a}$ \\
\hline & & $\mathrm{SD}[\mathrm{mV}]$ & $\mathrm{n} / \mathrm{a}$ & $\mathrm{n} / \mathrm{a}$ & $\mathrm{n} / \mathrm{a}$ & $\mathrm{n} / \mathrm{a}$ & 0.65 & 3.88 & $\mathrm{n} / \mathrm{a}$ & $\mathrm{n} / \mathrm{a}$ \\
\hline & & $\mathrm{p}$ & $\mathrm{n} / \mathrm{a}$ & $\mathrm{n} / \mathrm{a}$ & $\mathrm{n} / \mathrm{a}$ & $\mathrm{n} / \mathrm{a}$ & 1.000 & 0.935 & $\mathrm{n} / \mathrm{a}$ & $\mathrm{n} / \mathrm{a}$ \\
\hline \multirow{18}{*}{ Nano-Ag } & \multirow{3}{*}{ M1 HL } & Mean $[\mathrm{mV}]$ & -37.8 & -41.3 & $\mathrm{n} / \mathrm{a}$ & $\mathrm{n} / \mathrm{a}$ & -39.3 & -38.6 & -34.2 & -32.8 \\
\hline & & $\mathrm{SD}[\mathrm{mV}]$ & 4.33 & 1.03 & $\mathrm{n} / \mathrm{a}$ & $\mathrm{n} / \mathrm{a}$ & 1.14 & 2.64 & 1.90 & 2.58 \\
\hline & & $\mathrm{p}$ & 0.967 & 0.412 & $\mathrm{n} / \mathrm{a}$ & $\mathrm{n} / \mathrm{a}$ & 0.803 & 0.896 & 1.000 & 1.000 \\
\hline & \multirow{3}{*}{ M1 ST } & Mean $[\mathrm{mV}]$ & -35.5 & -30.4 & -34.1 & -24.2 & -39.8 & -39.2 & -35.1 & -34.3 \\
\hline & & $\mathrm{SD}[\mathrm{mV}]$ & 2.71 & 8.49 & 11.78 & 5.35 & 0.90 & 3.05 & 1.18 & 0.87 \\
\hline & & $\mathrm{p}$ & 0.923 & 1.000 & 0.999 & 1.000 & 0.269 & 0.355 & 0.948 & 0.983 \\
\hline & \multirow{3}{*}{ M2 HL } & Mean $[\mathrm{mV}]$ & -43.4 & -50 & -28.2 & -25.5 & -31.8 & -28.4 & -26 & -31.6 \\
\hline & & $\mathrm{SD}[\mathrm{mV}]$ & 3.97 & 4.3 & 4.31 & 0.61 & 4.66 & 4.58 & 1.39 & 0.7 \\
\hline & & $\mathrm{p}$ & 0.292 & 0.002 & 0.999 & 0.910 & 1.000 & 0.999 & 0.951 & 1.000 \\
\hline & \multirow{3}{*}{ M2 ST } & Mean $[\mathrm{mV}]$ & -34.9 & -37.1 & -37.8 & $\mathrm{n} / \mathrm{a}$ & $\mathrm{n} / \mathrm{a}$ & -29.8 & $\mathrm{n} / \mathrm{a}$ & $\mathrm{n} / \mathrm{a}$ \\
\hline & & $\mathrm{SD}[\mathrm{mV}]$ & 7.22 & 0.35 & 0.91 & $\mathrm{n} / \mathrm{a}$ & $\mathrm{n} / \mathrm{a}$ & 1.91 & $\mathrm{n} / \mathrm{a}$ & $\mathrm{n} / \mathrm{a}$ \\
\hline & & $\mathrm{p}$ & 0.960 & 0.711 & 0.595 & $\mathrm{n} / \mathrm{a}$ & $\mathrm{n} / \mathrm{a}$ & 1.000 & $\mathrm{n} / \mathrm{a}$ & $\mathrm{n} / \mathrm{a}$ \\
\hline & \multirow{3}{*}{ M3 HL } & mean $[\mathrm{mV}]$ & -45.5 & -41.5 & -25.5 & -40.9 & -38.6 & $\mathrm{n} / \mathrm{a}$ & $\mathrm{n} / \mathrm{a}$ & -31.3 \\
\hline & & $\mathrm{SD}[\mathrm{mV}]$ & 5.06 & 2.64 & 12.97 & 6.49 & 2.55 & $\mathrm{n} / \mathrm{a}$ & $\mathrm{n} / \mathrm{a}$ & 1.10 \\
\hline & & $\mathrm{p}$ & 0.834 & 0.999 & 0.116 & 0.999 & 1.000 & $\mathrm{n} / \mathrm{a}$ & $\mathrm{n} / \mathrm{a}$ & 0.967 \\
\hline & \multirow{3}{*}{ M3 ST } & Mean $[\mathrm{mV}]$ & -44.9 & -29.6 & -29.9 & -34.3 & $\mathrm{n} / \mathrm{a}$ & -35.9 & -30.5 & -27.5 \\
\hline & & $\mathrm{SD}[\mathrm{mV}]$ & 2.70 & 0.46 & 5.65 & 9.08 & $\mathrm{n} / \mathrm{a}$ & 2.35 & 2.51 & 3.79 \\
\hline & & $\mathrm{p}$ & 0.001 & 0.999 & 0.998 & 0.606 & $\mathrm{n} / \mathrm{a}$ & 0.340 & 0.993 & 1.000 \\
\hline
\end{tabular}




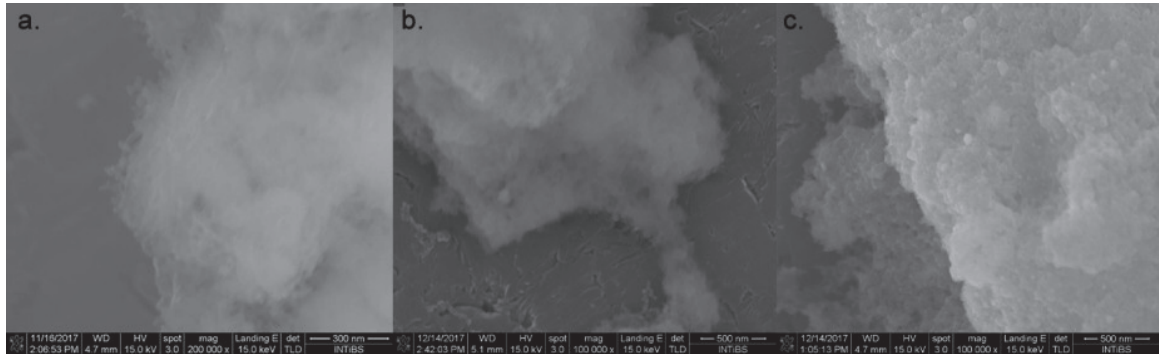

Fig. 3. SEM images of the humic acid nanoparticles with: a) $\mathrm{Cu}$, b) $\mathrm{Ag}$, c) $\mathrm{Zr}$.
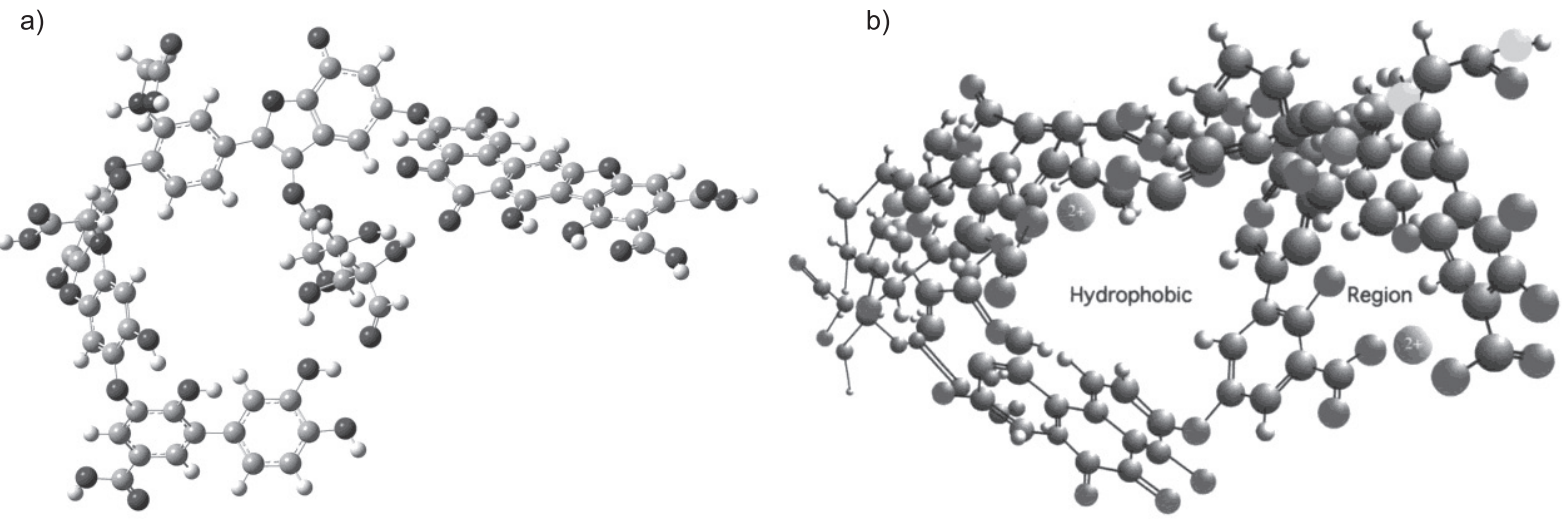

Fig. 4. Humic acid structure determined based on molecular modeling a) and proposed by Ray von Wandruszka b).
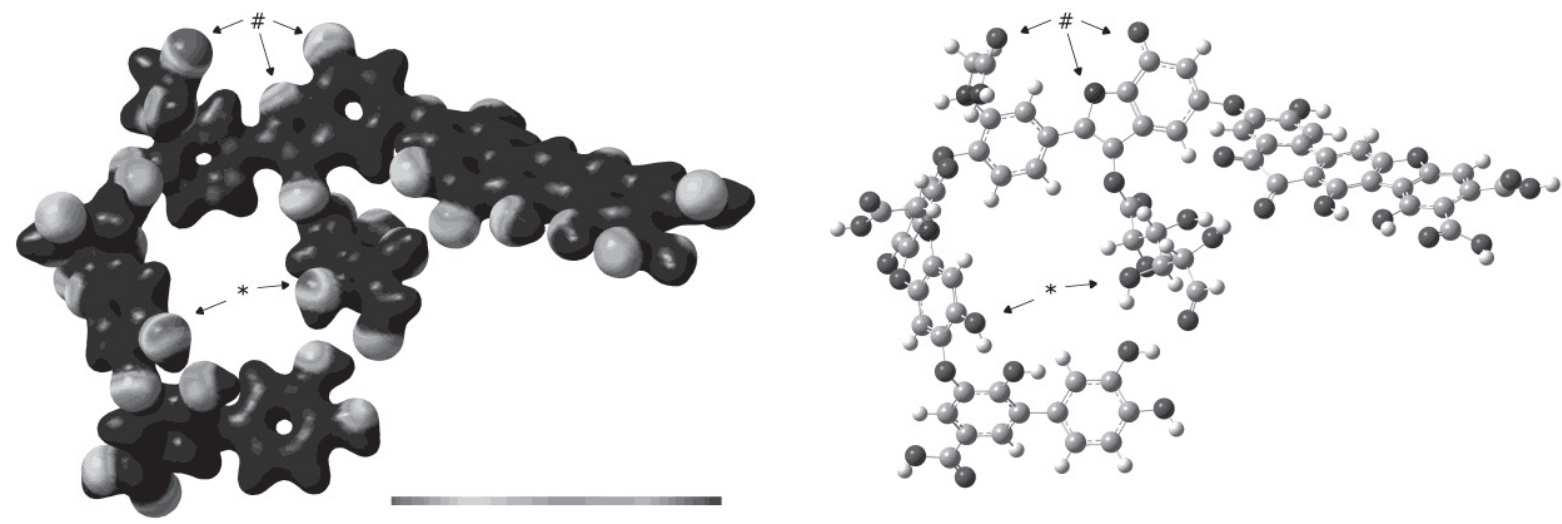

Fig. 5. Potential positions for ion docking in humic acid molecule.

derived from molecular modeling and the values from Table 3 were compared in Table 6.

The shortening of the distance $\mathrm{G}$ between oxygen and nitrogen atoms (bound through two carbon atoms) results clearly from the values of the radius (A and B)

Table 3. Values of atomic radius $[\AA][33]$.

\begin{tabular}{|c|c|c|c|c|c|c|}
\hline \multirow{2}{*}{$*$} & \multirow{2}{*}{ Atomic radius } & \multicolumn{5}{|c|}{ Atom } \\
\cline { 3 - 7 } & & $\mathrm{Cu}$ & $\mathrm{Ag}$ & $\mathrm{Zr}$ & $\mathrm{O}$ & $\mathrm{N}$ \\
\hline $\mathrm{A}$ & Empirical & 1.35 & 1.60 & 1.55 & 0.60 & 0.65 \\
\hline $\mathrm{B}$ & Covalent (single bond) & 1.38 & 1.53 & 1.48 & 0.73 & 0.75 \\
\hline
\end{tabular}

of the metal ion. The addition of a metal ion "pulls" the oxygen and nitrogen atom closer together, and their distance closely correlates with the radius of the added metal ion: the smaller the radius of the metal ion, the closer the oxygen and nitrogen atoms coordinated by that metal ion are to each other.

An analogous relationship can be observed for the distance F, i.e. between oxygen and nitrogen which are unbound when a metal ion is absent. The addition of a metal ion causes a change in the dihedral angles in the short side chain and "pulls" together the oxygen atom from the side chain and the nitrogen atom from the fivemembered ring. This distance directly depends on the radius of the coordinated metal ion. 
Table 4. Calculated values of the selected parameters of monohumic nanoparticle

\begin{tabular}{|c|c|c|c|c|}
\hline Parameter & \multicolumn{4}{|c|}{ Atom in "\#” position } \\
\hline & none & $\mathrm{Cu}$ & $\mathrm{Ag}$ & $\mathrm{Zr}$ \\
\hline Electronegativity of atom "\#” & - & 1.90 & 1.93 & 1.33 \\
\hline Dipole moment $[\mathrm{D}]$ & 22.6517 & 66.1406 & 68.6960 & 57.2955 \\
\hline Calculated diameter* $[\AA]$ & 28.6130 & 28.1801 & 28.2491 & 28.0227 \\
\hline Maximum diameter of "window"** $[\AA]$ & 6.8072 & 7.8943 & 7.8197 & 7.7010 \\
\hline
\end{tabular}

* distance of the centers of the most distant atoms

** diameter of cylinder from Fig. 6.

The huge change in the distance $F$ value (from $\sim 6 \AA$ to 3-4 $\AA$ ), caused by the addition of a metal ion, directly affects the equally large change in distance $\mathrm{E}$, i.e. oxygen atoms, which also correlates with the radius of the metal ion.
The values of the selected parameters of the tested nanoparticles were summarized in Table 4 . It can be seen, the dipole moment of the humic acid molecule increased about three times in each case after the metal ion has bound. What's more, the dipole moment

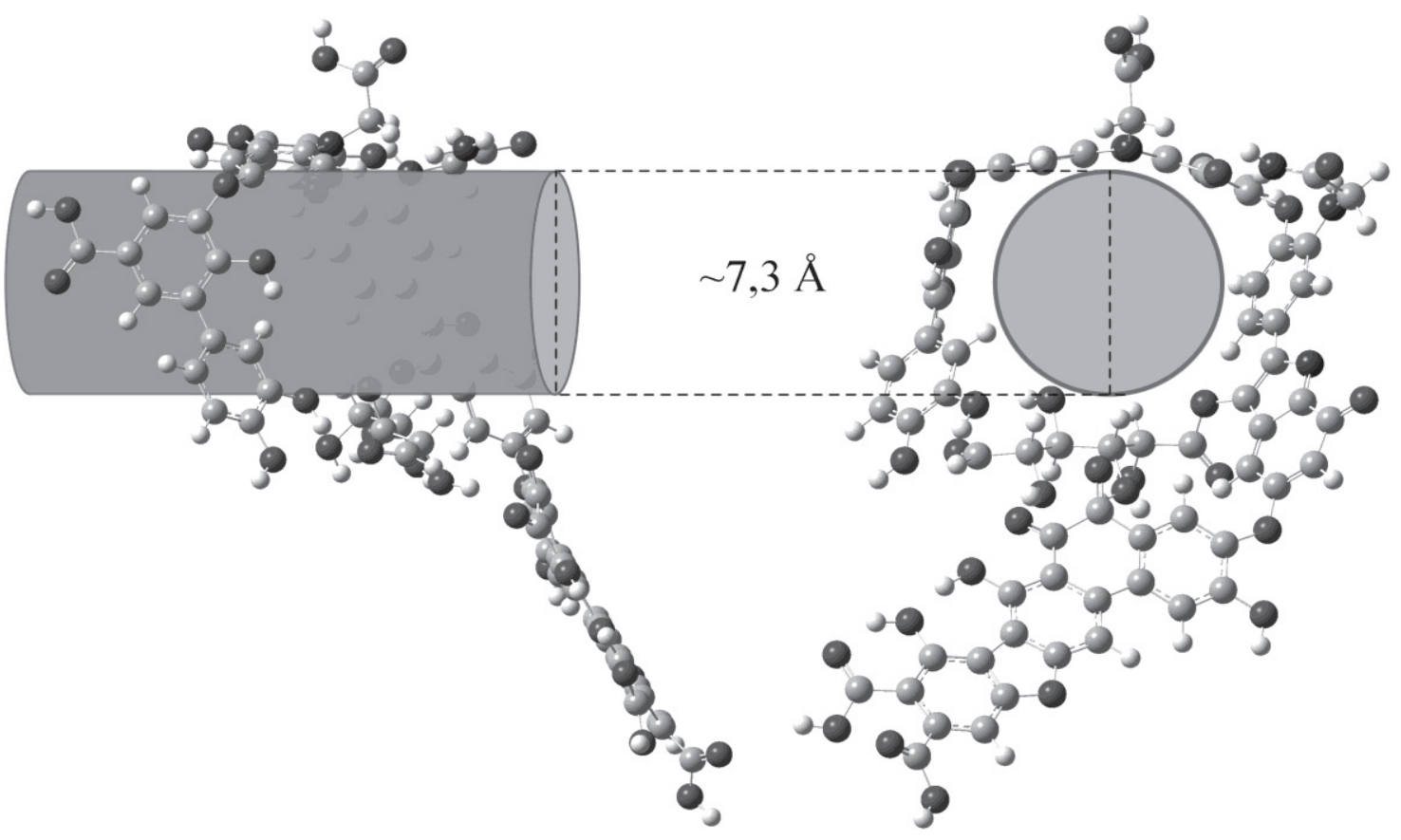

Fig. 6. Gap in coiled structure of humic acid.

Table 5. Calculated values of distances $[\AA]$ in monohumic nanoparticle.

\begin{tabular}{|c|c|c|c|c|c|}
\hline \multirow{2}{*}{} & \multirow{2}{*}{ Atoms } & \multicolumn{4}{|c|}{ Atom in “\#” position } \\
\cline { 3 - 6 } & & None & $\mathrm{Cu}$ & $\mathrm{Ag}$ & $\mathrm{Zr}$ \\
\hline $\mathrm{C}$ & $\mathrm{O}, \mathrm{H}$ (hydrogen bond) & 1.8141 & 1.6427 & 1.6524 & 1.6359 \\
\hline $\mathrm{D}$ & $\mathrm{O}, \mathrm{H}$ (hydrogen bond) & 1.8433 & 1.5952 & 1.5791 & 1.5575 \\
\hline $\mathrm{E}$ & $\mathrm{O}, \mathrm{O}$ & 6.9254 & 3.4214 & 4.4638 & 4.0096 \\
\hline F & $\mathrm{O}, \mathrm{N}$ & 5.9281 & 3.1343 & 3.9978 & 3.6268 \\
\hline $\mathrm{G}$ & $\mathrm{O}, \mathrm{N}$ & 2.9416 & 2.6374 & 2.8908 & 2.6821 \\
\hline $\mathrm{H}$ & $\mathrm{O}, \mathrm{O}$ & 2.7496 & 2.6649 & 2.6737 & 2.6601 \\
\hline $\mathrm{I}$ & $\mathrm{O}, \mathrm{O}$ & 2.7192 & 2.5542 & 2.5513 & 2.5384 \\
\hline
\end{tabular}


Table 6. Calculated values of selected bonds $[\AA]$ in monohumic nanoparticle.

\begin{tabular}{|c|c|c|c|c|c|}
\hline & \multirow{2}{*}{ Bond } & \multirow{2}{*}{ Bond length $[\AA]$ resulting from } & \multicolumn{3}{|c|}{ Atom in "\#" position } \\
\hline & & & $\mathrm{Cu}$ & $\mathrm{Ag}$ & $\mathrm{Zr}$ \\
\hline \multirow{3}{*}{$\mathrm{J}$} & \multirow{3}{*}{$\#-\mathrm{O}$} & Molecular-modeling & 1.7950 & 2.2137 & 2.1485 \\
\hline & & Sum of atomic radius from Table 3 , line $\mathrm{A}$ & 1.95 & 2.20 & 2.15 \\
\hline & & Sum of atomic radius from Table 3 , line $B$ & 2.11 & 2.26 & 2.21 \\
\hline \multirow{3}{*}{ K } & \multirow{3}{*}{$\#-\mathrm{O}$} & Molecular-modeling & 1.8537 & 2.3377 & 1.9771 \\
\hline & & Sum of A from Table 3 & 1.95 & 2.20 & 2.15 \\
\hline & & Sum of B from Table 3 & 2.11 & 2.26 & 2.21 \\
\hline \multirow{3}{*}{$\mathrm{L}$} & \multirow{3}{*}{$\#-\mathrm{N}$} & Molecular-modeling & 1.8162 & 2.4110 & 2.0580 \\
\hline & & Sum of A from Table 3 & 2.00 & 2.25 & 2.20 \\
\hline & & Sum of B from Table 3 & 2.13 & 2.28 & 2.23 \\
\hline
\end{tabular}

value of the nanoparticle increased with the growth in electronegativity of the coordinated metal ion.

The diameter of the entire nanoparticle also increased with the increase of electronegativity of the metal ion, however in all cases diameter was smaller than for a molecule without a metal ion by about

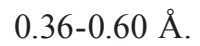

The presence of metal ion influences the size of "window". The "window" diameter was clearly larger (by about $0.9-1.1 \AA$ ) in the case of nanoparticles with coordinating of a metal ion. However, changes depending on the kind of metal ion were not be seen either in relation to electronegativity or the ion diameter according to Table 4.

The distances between the oxygen atoms coordinating the metal ion were changed slightly (max. $0.02 \AA$ ) depending on the kind of metal ion. These distances decreased slightly compared to the distances in the acid molecule without a metal ion.

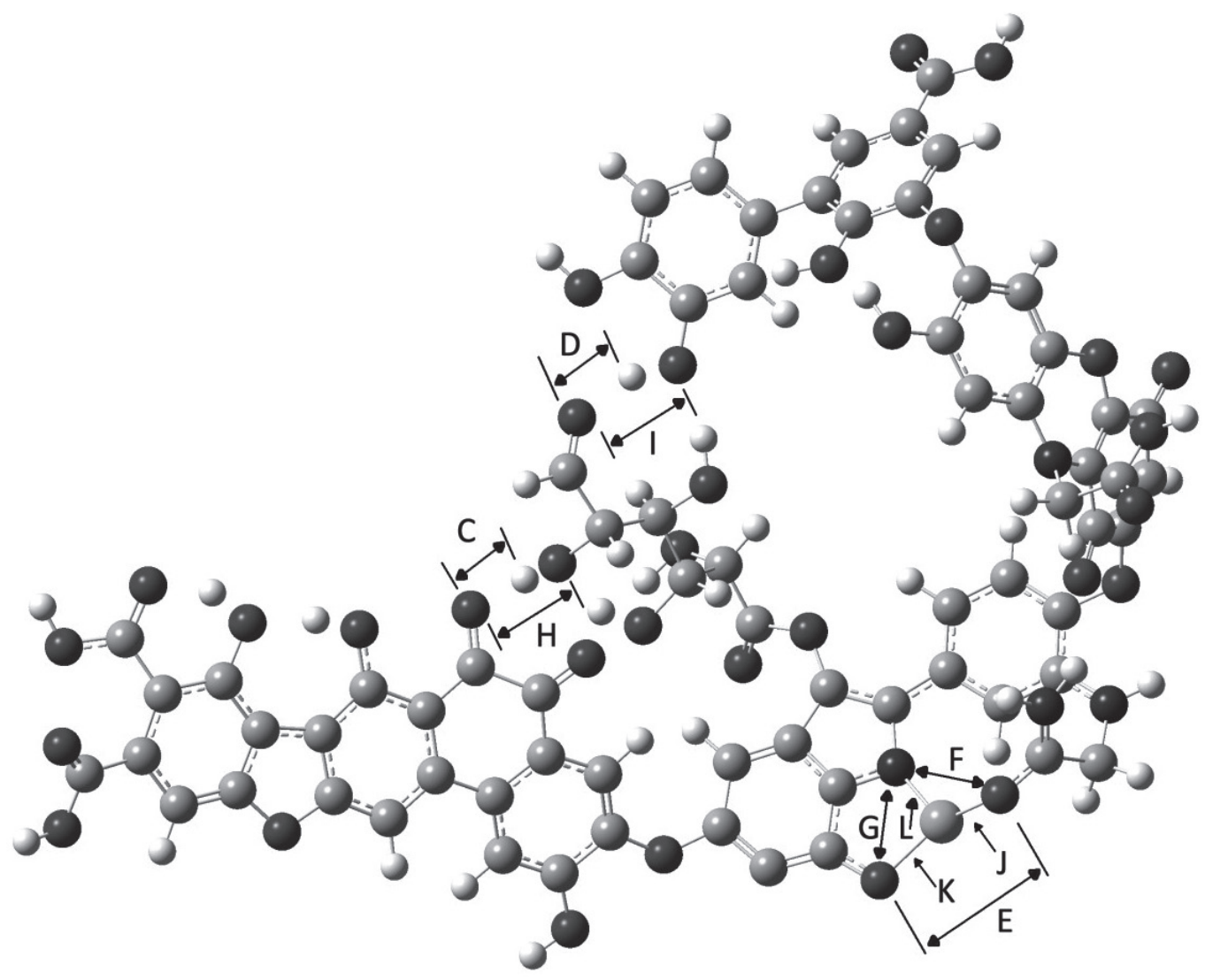

Fig. 7. Selected bonds and distances in humic acid molecule described in Table 4 and Table 5. 


\section{Discussion}

In the work, the nanoparticles of peat components, i.e. humic acid and fulvic acid with silver, zirconium and copper ions were obtained. The conducted tests (NTA and DLS) shown that the smallest size (smaller than $50 \mathrm{~nm}$ ) have the nanoparticles with silver but at the same time they are unstable. Their zeta potential was smaller than $-30 \mathrm{mV}$. In turn, the size of particles with zirconium and copper was much bigger $(20-200 \mathrm{~nm})$ and they were stable (zeta potential was in the range $-24 \div 0 \mathrm{mV}$ ). It is known, the nanoparticle is stable when the zeta potential has the value in the range $-30 \mathrm{mV}$ and $+30 \mathrm{mV}[34,35]$.

Such big size of the resulting particles was caused by aggregation of them. Nanoparticles agglomerated and sedimented because of the intermolecular interactions and hydrogen bonds. The measured size of particles was not the size of single particle. By means of SEM analysis, it was possible to distinguish a single particle in the aggregates. Both sonication and attempts to mechanical separation of the aggregates were unsuccessful. It was not possible to separate the agglomerates into single nanoparticles to measure them precisely. In order to estimate the size of the resulted nanoparticles, TEM analysis of the nanoparticles was performed. It was observed that the particles diameter is about $5 \mathrm{~nm}$.

The SEM-EDX analysis of the resulting nanoparticles demonstrated the compliance of the calculated and found shares of key metals.

The obtained silver, zirconium and copper nanoparticles, formed due to the interaction of appropriate ions with humic acids, constitute precipitation of the oxidized forms of these heavy metals. They are retained and accumulated in the peat as presumably non-toxic nanoparticles of these metals, which is extremely important from the point of view of environmental protection.

In the next part of work, in order to explain the way of nanoparticles formation, molecular modeling of the peat components with the tested ions was performed.

It was supposed that fulvic acid which amount is twice higher in peat $[30,31]$ and which molecule size is much smaller than humic acid molecule should bind with metal ions much better. However, despite their significantly big size and limited mobility, humic acids are more likely to "bind" to the metal ion more strongly than fulvic acids [22].

The results of numerous simulations of possible combinations of metal ions with fulvic acids pointed to the existence of only one metal-acid bond in such nanoparticle, resulting in a fulvic acid salt. In contrast, the structure of the humic acid molecules, even in its simplest form, (i.e. from the beginning of the homologous series) offered coordination of the metal ion with three single bonds. It happened due to the specific spatial structure of the humic acid molecule, also proposed earlier by Engebretson and von Wandruszka [15] (see Fig. 4).

More detailed analysis of the results of the spatial optimization of humic acid indicated that the folding of the structure was the most stable conformation of molecule which enabled permanent three-coordination of metal ion. The folding of humic acid molecule resulted from the formation of a "window" in its structure (indicates by "\#” in Fig. 5) . Molecule in this conformation could trap a metal ion. The second place of potential attachment of a metal ion (marked with “*” in Fig. 5) was possible but the probability of an attachment was much smaller.

According to Wandruszka, the formation of a "window" allowed binding the metal ions, e.g. $\mathrm{Mg}^{2+}$. The author postulated that the structure created in this way would be energetically beneficial and therefore stable.

Molecular modeling proved that humic acid exists always in the form of fold structure, even in the lack of metal ion. When a metal ion appears the humic acid window diameter changes a bit but. The suitable data of bond length, in humic acid molecule and in nanoparticles with metal ion, resulted from of calculations and literature date were juxtapositioned in Tables 3-6.

In addition, Wandruszka postulated that the nanoparticle size would be max. $10 \mathrm{~nm}$ and all obtained nanoparticles would be identical in shape and size. Quantum-mechanical calculations prove that one nanoparticle should have a hydrodynamic diameter of max. $5 \mathrm{~nm}$ and nanoparticles should be different in shapes and sizes depending on the type of metal ion.

\section{Conclusions}

Nanoparticles with the following ions: copper, silver and zirconium were formed with the peat components. The nanoparticles have various shapes and sizes depend on the type of metal ion.

The nanoparticles underwent agglomeration and sedimentation therefore the measured diameter was even $250 \mathrm{~nm}$. SEM and TEM analyses indicted that real size of single particles is about $5 \mathrm{~nm}$.

Molecular modeling allowed to determine that humic acid can form nanoparticles with metal ions more likely than fulvic acid. In the case of fulvic acid only salt was formed. In turn, humic acid was able to coordinate metal ion.

The folding structure of humic acid was the most energetically stable conformation of molecule. It resulted from the possibility of a "window" formation due to intramolecular interactions. The "window" diameter changed the size slightly depending the type of ion metal. The most stable conformation of humic acid molecule enabled permanent triple-coordination of metal ion. Molecular modeling proved that humic acid existed always in the form of fold structure, even 
in the lack of metal ion in contrast to Wandruszka postulations.

Molecular modeling indicated the stable structure of the humic acid molecule, the places of potential attachment of the metal ion, and helped in visualize the model of the obtained nanoparticle. Based on the calculations, the explanation of the way nanoparticles formation was possible.

\section{Acknowledgements}

The authors would like to thank Interdisciplinary Centre for Mathematical and Computational Modelling in Warsaw for providing computer facilities for the possibility of performing of the quantum-mechanical calculations under grant No. G49-12.

The authors would like to thank National Science Center for grant No. 2012/07/N/NZ9/02137.

The authors would like to thank the Centre for Radiobiology and Biological Dosimetry at the Institute of Nuclear Chemistry and Technology, in Warsaw (Poland) for the measurements of size distribution of nanoparticles.

The authors would like to thank the Institute of Low Temperature and Structure Research of Polish Academy of Science, in Wroclaw (Poland) for SEM and TEM measurements.

\section{Conflict of Interest}

The authors declare no conflict of interest.

\section{References}

1. HULKOTI N.A., TARANATH T.C. Biosynthesis of nanoparticles using microbes - A review. Colloids and Surfaces B: Biointerfaces, 121, 474, 2014.

2. KUMAR C.G., MAMIDYALA S.K., REDDY M.N., REDDY B.V.S. Silver glyconanoparticles functionalized with sugars of sweet sorghum syrup as an antimicrobial agent. Process Biochemistry, 47 (10), 1488, 2012.

3. JAIN S., MEHATA M.S. Medicinal plant leaf extract and pure flavonoid mediated green synthesis of silver nanoparticles and their enhanced antibacterial property. Scientific Reports, 7, 15867, 2017.

4. NIDHI S., SONI D., CHANDRASHEKHAR B., SATPUTE D.B., SARAVANADEVI S., SARANGI B.K., PANDEY R.A. Synthesis of silver nanoparticles using flavonoids: hesperidin, naringin and diosmin, and their antibacterial effects and cytotoxicity. International Nano Letters, 6, 173, 2016.

5. KANNAN R.R.R., ARUMUGAM R., RAMYA D., MANIVANNAN K., ANANTHARAMAN P. Green synthesis of silver nanoparticles using marine macroalga Chaetomorpha linum, Applied Nanoscience, 3, 229, 2013.

6. TERENTEVA E.A., APYARI V.V., DMITRIENKO S.G., ZOLOTOV Y.A. Formation of plasmonic silver nanoparticles by flavonoid reduction: A comparative study and application for determination of these substances. Spectrochimica Acta Part A: Molecular and Biomolecular Spectroscopy, 151, 89, 2015.

7. KABATA-PENDIAS A., PENDIAS H. Trace elements in soils and plants. Fla: CRC Press, Boca Raton, 2001.

8. RADOMSKII S.M., RADOMSKAYA V.I., MOISEENKO N.V., MOISEENKO V.G. Nanoparticles of noble metals in peat of the Upper and Middle Amur Region. Doklady Earth Sciences, 426 (4), 620, 2009.

9. SHAW A.J. Heavy metal tolerance in plants: Evolutionary aspects. Fla: CRC Press, Boca Raton, 1990.

10. PARK J.H., LAMB D., PANEERSELVAM P., CHOPPALA G., BOLAN N., CHUNG J.W. Role of organic amendments on enhanced bioremediation of heavy metal(loid) contaminated soils. Journal of Hazardous Materials, 185, 549, 2011.

11. WU L.H., LUO Y.M., CHRISTIE P., WONG M.H. Effects of EDTA and low molecular weight organic acids on soil solution properties of a heavy metal polluted soil. Chemosphere, 50, 819, 2003.

12. SMAL H., MISZTAL M. Soil solution chemistry in the profiles of forest and arable light textured soils, SE Poland. Applied Geochemistry, 11, 81,1996.

13. HONGVE D., VAN HEES PAW, LUNDSTRÖM U.S. Dissolved components in precipitation water percolated through forest litter. European Journal of Soil Science, 5, $667,2000$.

14. KARCZEWSKA A. Historically contaminated sites and their remediation in the light of Act on environmental protection amended in 2014-selected cases from SouthWestern Poland. Zeszyty Naukowe Uniwersytetu Przyrodniczego we Wrocławiu-Rolnictwo, 111, 51, 2014.

15. NGEBRETSON R.R., von WANDRUSZKA R. Microorganization in dissolved humic acids. Environ. Sci. Technol., 28, 1934, 1994.

16. CZERNIECKA-KUBICKA A., FRĄCZ W., JASIORSKI M., BŁAŻEJEWSKI, W., PILCH-PITERA B., PYDA M., ZARZYKA I. Thermal properties of poly(3hydroxybutyrate) modified by nanocla. J. Therm. Anal. Calorim., 125, 1513, 2017.

17. SINGH B., RANI M., SINGH J., MOUDGIL L., SHARMA P., KUMAR S., SAINI G.S.S., TRIPATHI S.K., SINGHD G., KAURA A. Identifying the preferred interaction mode of naringin with gold nanoparticles through experimental, DFT and TDDFT techniques: insights into their sensing and biological applications. RSC Adv., 6, 79470, 2016.

18. GRIFFITHS D., CARNELL-MORRIS P., WRIGHT M. Nanoparticle tracking analysis for multiparameter characterization and counting of nanoparticle suspensions. Methods in molecular biology, Clifton, N.J., 2118, 289, 2020.

19. CHEN Z.H., KIM C., ZENG X., HWANG S.H., JANG J., UNGAR G. Characterizing size and porosity of hollow nanoparticles: SAXS, SANS, TEM, DLS, and adsorption isotherms compared, Langmuir, 28 (43), 15350, 2012.

20. CAMETTI M., DŽOLIĆ Z. New frontiers in hybrid materials: noble metal nanoparticles - supramolecular gel systems. Chem. Commun., 50, 8273, 2014.

21. VADLAPUDI V., KALADHAR D.S.V.G.K., BEHARA M., SUJATHA B., NAIDU G.K. Synthesis of green metallic nanoparticles (NPs) and applications. Oriental Journal of Chemistry, 29 (4), 2014.

22. DZIADOWIEC H., GONET S. Methodological guidebook for soil organic matter studies. Works of the Scientific Committees of the Polish Soil Science Society, Warsaw, 1999. 
23. FRISCH M.J., TRUCKS G.W., SCHLEGEL H.B., SCUSERIA G.E., ROBB M.A., CHEESEMAN J.R., SCALMANI G., BARONE V., PETERSSON G.A., NAKATSUJI H., LI X., CARICATO M., MARENICH A.V., BLOINO J., JANESKO B.G., GOMPERTS R., MENNUCCI B., HRATCHIAN H.P., ORTIZ J.V., IZMAYLOV A.F., SONNENBERG J.L., WILLIAMSYOUNG D., DING F., LIPPARINI F., EGIDI F., GOINGS J., PENG B., PETRONE A., HENDERSON T., RANASINGHE D., ZAKRZEWSKI V.G., GAO J., REGA N., ZHENG G., LIANG W., HADA M., EHARA M., TOYOTA K., FUKUDA R., HASEGAWA J., ISHIDA M., NAKAJIMA T., HONDA Y., KITAO O., NAKAI H., VREVEN T., THROSSELL K., MONTGOMERY J.A.JR., PERALTA J.E., OGLIARO F., BEARPARK M. J., HEYD J.J., BROTHERS E.N., KUDIN K.N., STAROVEROV V.N., KEITH T.A., KOBAYASHI R., NORMAND J., RAGHAVACHARI K., RENDELL A.P., BURANT J.C., IYENGAR S.S., TOMASI J., COSSI M., MILLAM J.M., KLENE M., ADAMO C., CAMMI R., OCHTERSKI J.W., MARTIN R.L., MOROKUMA K., FARKAS O., FORESMAN J.B., FOX D.J. Gaussian 16, Revision C.01, Wallingford CT: Gaussian, Inc., 2016.

24. KRÓL A., RAILEAN-PLUGARU V., POMASTOWSKI P., BUSZEWSKI B. Phytochemical investigation of Medicago sativa L. extract and its potential as a safe source for the synthesis of $\mathrm{ZnO}$ nanoparticles: The proposed mechanism of formation and antimicrobial activity. Phytochemistry Letters, 31, 170, 2019.

25. RAI M., POSTEN C. Green biosynthesis of nanoparticles: mechanisms and applications. Wallingford, Oxfordshire; Boston, Massachusetts: C.A.B. International, 2013.

26. OMIDI S., SEDAGHAT S., TAHVILDARI K., DERAKHSHI P., MOTIEE F. Biosynthesis of silver nanocomposite with Tarragon leaf extract and assessment of antibacterial activity. J. Nanostruct. Chem. 8, 171, 2018.
27. BANSAL A., KAUR K. Silver nanoparticles - green synthesis through medicinal plants extract and its antimicrobial prospects. Journal of Biology and Nature, 11 (2), 34, 2020.

28. PUNNIYAKOTTI P., PANNEERSELVAM P., PERUMAL D., ARULIAH R., ANGAIAH S. Anti-bacterial and anti-biofilm properties of green synthesized copper nanoparticles from Cardiospermum halicacabum leaf extract. Bioprocess and Biosystems Engineering, 2020.

29. NIKAM A., PAGAR T., GHOTEKAR S., PAGAR K., PANSAMBAL S. A review on plant extract mediated green synthesis of zirconia nanoparticles and their miscellaneous applications. Journal of Chemical Reviews, 1 (3), 154, 2019.

30. STEVENSON F.J. Humus Chemistry: Genesis, Composition, Reactions (2nd ed.). John Wiley \& Sons, 1994.

31. PICCOLO A. The supramolecular structure of humic substances: A novel understanding of humus chemistry and implications in soil science. Advances in Agronomy, 75, 57, 2002.

32. von WANDRUSZKA R. Humic acids: Their detergent qualities and potential uses in pollution remediation. Geochem. Trans., 1, 10, 2000.

33. Atomic radii of the elements (data page) - Wikipedia. Available online: https://en.wikipedia.org/wiki/Atomic radii_of_the_elements_(data_page) (accessed on 9 May 2020)

34. WISSING S., MÜLLER R. Solid lipid nanoparticles as carrier for sunscreens: in vitro release and in vivo skin penetration. J. Controlled Release, 81, 225, 2002.

35. POMASTOWSKI P., DZIUBAKIEWICZ E., BUSZEWSKI B. Zeta potential, its role and meaning. Analytics: Science and Practice, 2, 19, 2012. 